University of Nebraska - Lincoln

DigitalCommons@University of Nebraska - Lincoln

USDA National Wildlife Research Center - Staff Publications
U.S. Department of Agriculture: Animal and Plant Health Inspection Service

February 2007

\title{
Bioeconomic analysis of herpetofauna road-kills in a Florida state park
}

Stephanie A. Shwiff

USDA/APHIS/WS National Wildlife Research Center, stephanie.a.shwiff@aphis.usda.gov

Henry T. Smith

Florida Department of Environmental Protection, Florida Park Service

Richard M. Engeman

USDA-APHIS-Wildlife Services, s_r100@yahoo.com

Robert M. Barry

Palm Beach Community College

Robin J. Rossmanith

Jonathan Dickinson State Park

See next page for additional authors

Follow this and additional works at: https://digitalcommons.unl.edu/icwdm_usdanwrc

Part of the Environmental Sciences Commons

Shwiff, Stephanie A.; Smith, Henry T.; Engeman, Richard M.; Barry, Robert M.; Rossmanith, Robin J.; and Nelson, Mark, "Bioeconomic analysis of herpetofauna road-kills in a Florida state park" (2007). USDA National Wildlife Research Center - Staff Publications. 623.

https://digitalcommons.unl.edu/icwdm_usdanwrc/623

This Article is brought to you for free and open access by the U.S. Department of Agriculture: Animal and Plant Health Inspection Service at DigitalCommons@University of Nebraska - Lincoln. It has been accepted for inclusion in USDA National Wildlife Research Center - Staff Publications by an authorized administrator of DigitalCommons@University of Nebraska - Lincoln. 


\section{Authors}

Stephanie A. Shwiff, Henry T. Smith, Richard M. Engeman, Robert M. Barry, Robin J. Rossmanith, and Mark Nelson 


\title{
ANALYSIS
}

\section{Bioeconomic analysis of herpetofauna road-kills in a Florida state park}

\author{
Stephanie A. Shwiff ${ }^{a}$, Henry T. Smith ${ }^{b, c}$, Richard M. Engeman ${ }^{a, *}$, \\ Robert M. Barry ${ }^{d, 1}$, Robin J. Rossmanith ${ }^{e}$ Mark Nelson $^{e}$ \\ ${ }^{a}$ National Wildlife Research Center, 4101 LaPorte Avenue, Fort Collins, Colorado 80521-2154, USA \\ ${ }^{\mathrm{b}}$ Florida Department of Environmental Protection, Florida Park Service, 13798 S.E. Federal Highway, Hobe Sound, Florida 33455, USA \\ ${ }^{c}$ Florida Atlantic University, Wilkes Honors College, 5353 Parkside Drive, Jupiter, Florida 33458, USA \\ dPalm Beach Community College, 4200 Congress Avenue, Lake Worth, Florida 33461, USA \\ eJonathan Dickinson State Park, 16450 S.E. Federal Highway, Hobe Sound, Florida 33455, USA
}

\section{A R T I C L E I N F O}

\section{Article history:}

Received 5 October 2006

Received in revised form

19 January 2007

Accepted 11 February 2007

\section{Keywords:}

\section{Amphibian}

Benefit-cost ratio

Florida

Jonathan Dickinson State Park

Reptile

Species values

\begin{abstract}
A B S T R A C T
Road-kills are a major cause of mortality for a wide variety of herpetofauna, but management decisions on remediation procedures for reducing losses are based in economic realities. Because funding is finite for species conservation, bioeconomic analysis can assist in justifying, evaluating, and maximizing returns on conservation expenditures, especially for low-profile species such as herpetofauna. Here, we present a bioeconomic analysis of road-killed herpetofauna in Jonathan Dickinson State Park, Florida. Road surveys were conducted daily for four years to identify and enumerate the numbers of each reptile and amphibian species killed by vehicles. Conservative individual valuations applied to the losses formed the basis of a benefit-cost analysis aimed at identifying the thresholds at which remediation expenditures would be justified. We found an average of 64 reptiles and amphibians were killed/year, justifying conservation expenditures up to $\$ 32,000 /$ year. However, if less conservative valuations were applied, especially for threatened and endangered species, justifiable expenditures rise dramatically.
\end{abstract}

C 2007 Elsevier B.V. All rights reserved.

\section{Introduction}

Road-kills of herpetofauna are a major cause of mortality for a wide variety of taxa (Ashley and Robinson, 1996; Haxton, 2000; Trombulak and Frissell, 2000; Hels and Buchwald, 2001). However, management decisions to implement actions for reducing losses are based in economic realities, and herpetofauna often are low-profile species. Funding is finite for species conservation and must be carefully applied to maximize its positive impact. Economic valuation and analysis of the losses can assist in evaluation and justification of remediation activities. We collected four years of herpetofauna road-kills from a south Florida state park. We economically valued those losses and conducted benefit-cost analyses to determine at what expenditures potential management actions would be justified.

\footnotetext{
* Corresponding author. Tel.: +1970 266 6091; fax: +1970 2666089.

E-mail address: richard.m.engeman@aphis.usda.gov (R.M. Engeman).

${ }^{1}$ Present address: Barrytours of Panama, Apartado 12510, Zona 6a, El Dorado Panama, Republic of Panama.
} 


\section{Methods}

\subsection{Study area}

Jonathan Dickinson State Park (JDSP) is a 4644.1 ha mixed-use state park located in Hobe Sound, on Florida's southeast coast. JDSP is a mix of uplands and wetlands, consisting mostly of seven vegetation community cover types: wet pine flatwoods (1983.8 ha), scrub (935.2 ha), strand swamp (370.9 ha), wet prairie (351.8 ha), scrubby flatwoods (234.8 ha), depression marsh (176.5 ha), and floodplain swamp (117.4 ha) (Office of Park Planning, GIS data). Approximately $10 \mathrm{~km}$ of paved, two-lane roads traverse the park, with speed limits ranging from 24.2 to $48.4 \mathrm{~km} / \mathrm{h}$. Fifty four native reptile and amphibian species are known to inhabit the park. Among these, five are either state and/or federally listed as threatened, endangered or a species of concern (Florida Department of Environmental Protection, 2000).

\subsection{Surveys}

A daily (7 days/week) road-kill survey was conducted during 1995-1998 by JDSP Park Rangers and consisted of slowly searching road surfaces (ca. $8-24 \mathrm{~km} / \mathrm{h}$ ) for dead wildlife, as reported for other state parks (Smith et al., 1994; Bard et al., 2002; Smith et al., 2003). Surveys were initiated between 7:45 and 8:15 a.m. Reptile and amphibian (as well as other vertebrate wildlife taxa) struck by vehicles were examined. Road-kills were identified and recorded to the species level, if possible. Their locations were noted to avoid being double counted on subsequent days.

\subsection{Economic valuations}

Determination of monetary values for wildlife species is not a straight-forward nor precise process. As an illustration, values of endangered or threatened species have been deemed "incalculable" in U.S. Supreme Court case law (Tennessee Valley Authority vs. Hill, 1978), the opinion going so far as to say "it would be difficult for a court to balance the loss of a sum certain - even $\$ 100$ million - against a congressionally declared 'incalculable' value, even assuming we had the power to engage in such a weighing process, which we emphatically do not." Despite that assessment, astronomically high monetary species valuations would be unlikely to be widely viewed as credible. Nevertheless, conservative monetary values for wildlife species can be estimated.

State wildlife and fisheries management agencies apply economic values based on contributions to the economy by individual game species (Bodenchuk et al., 2002). These economic values serve as the basis for civil financial penalties for illegal kills resulting from poaching, environmental contamination, or other "takes" (Bodenchuk et al., 2002). Except in rare cases, reptile and amphibian species do not have civil financial penalties assigned in relation to their contributions to the economy as "renewable" resources, because they are rarely exploited in a financially measurable fashion such as sales of hunting or fishing licenses and sportsman equipment. While not exploited as a "renewable" resource, these species are usually protected with civil penalties set forth legislatively.
Legislatively based species valuations have proven useful in a variety of applications for analyzing the economics of actual or potential management actions aimed at species conservation (e.g., Engeman et al., 2002, 2003, 2004; Shwiff et al., 2003; Smith et al., 2003). Many species may have more than one value available from multiple enabling legislations (e.g., United States federal and individual state laws). Multiple applicable civil penalties pose a dilemma as to which to incorporate into an economic analysis. In Florida, minimum monetary values for wildlife resources (penalties assessed for illegal "take") are specified in both statute and administrative code (Florida Statutes 370.021(5)d-f; Florida Administrative Code 39-27.002, 39-27.011, and 39-4.001). Likewise, federal laws also are applicable to some species which impose greater values (e.g., Endangered Species Act). We used the State of Florida wildlife values (Engeman et al., 2002; Shwiff et al., 2003; Smith et al., 2003) for our economic analysis, where the Wildlife Code of the State of Florida specifies up to a $\$ 500$ fine for "take" applicable to all wildlife in section 39-4.001 F.A.C. Given the variety of herpetofauna analyzed by this study, we also applied a range of conservative values in a benefit-cost analysis. A value of $\$ 250$ was used to represent half of the civil penalty value and $\$ 100$ was used to examine the benefits and costs of potential programs given extremely conservative values for the herpetofauna. This range of values provided a more extensive evaluation of

Table 1 -Species and dollar value of reptile and amphibian road-kills, 1995-1998, Jonathan Dickinson State Park, Florida

\begin{tabular}{lrlll} 
Species & \multicolumn{4}{c}{ Dollar value } \\
\cline { 2 - 5 } & No. lost & $\$ 100$ & $\$ 250$ & $\$ 500$ \\
\hline Florida box turtle & 3 & $\$ 300$ & $\$ 750$ & $\$ 1500$ \\
Gopher tortoise & 15 & $\$ 1500$ & $\$ 3750$ & $\$ 7500$ \\
Unidentified aquatic turtle & 1 & $\$ 100$ & $\$ 250$ & $\$ 500$ \\
Florida scrub lizard & 1 & $\$ 100$ & $\$ 250$ & $\$ 500$ \\
Glass lizard & 5 & $\$ 500$ & $\$ 1250$ & $\$ 2500$ \\
Dusky pygmy rattlesnake & 12 & $\$ 1200$ & $\$ 3000$ & $\$ 6000$ \\
Eastern diamondback & 4 & $\$ 400$ & $\$ 1000$ & $\$ 2000$ \\
rattlesnake & & & & \\
Eastern coral snake & 6 & $\$ 600$ & $\$ 1500$ & $\$ 3000$ \\
Rough green snake & 22 & $\$ 2200$ & $\$ 5500$ & $\$ 11,000$ \\
Black racer & 42 & $\$ 4200$ & $\$ 10,500$ & $\$ 21,000$ \\
Eastern coachwhip & 5 & $\$ 500$ & $\$ 1250$ & $\$ 2500$ \\
Eastern corn snake & 36 & $\$ 3600$ & $\$ 9000$ & $\$ 18,000$ \\
Scarlet kingsnake & 4 & $\$ 400$ & $\$ 1000$ & $\$ 2000$ \\
Florida pine snake & 2 & $\$ 200$ & $\$ 500$ & $\$ 1000$ \\
Eastern indigo snake & 1 & $\$ 100$ & $\$ 250$ & $\$ 500$ \\
Garter/ribbon snakes & 41 & $\$ 4100$ & $\$ 10,250$ & $\$ 20,500$ \\
Eastern mud snake & 1 & $\$ 100$ & $\$ 250$ & $\$ 500$ \\
South Florida swamp snake & 1 & $\$ 100$ & $\$ 250$ & $\$ 500$ \\
Florida water snake & 1 & $\$ 100$ & $\$ 250$ & $\$ 500$ \\
Unidentified snakes & 10 & $\$ 1000$ & $\$ 2500$ & $\$ 5000$ \\
American alligator & 4 & $\$ 400$ & $\$ 1000$ & $\$ 2000$ \\
Southern leopard frog & 2 & $\$ 200$ & $\$ 500$ & $\$ 1000$ \\
Pig frog & 1 & $\$ 100$ & $\$ 250$ & $\$ 500$ \\
Gopher frog & 1 & $\$ 100$ & $\$ 250$ & $\$ 500$ \\
Unidentified anurans & 35 & $\$ 3500$ & $\$ 8750$ & $\$ 17,500$ \\
Total & 256 & $\$ 25,600$ & $\$ 64,000$ & $\$ 128,000$ \\
Average/year & 64 & $\$ 6,400$ & $\$ 16,000$ & $\$ 32,000$ \\
\hline & & & & \\
\hline
\end{tabular}


Table 2-Annual benefit-cost ratios for differing management costs to avert an average of 64 amphibian and reptile road kills in Jonathan Dickinson State Park Florida, where animals are valued at $\$ 100, \$ 250$, and $\$ 500$ each

\begin{tabular}{lccc} 
Management & \multicolumn{3}{c}{ Value of annual loss } \\
\cline { 2 - 4 } cost (annual) & $\$ 6400$ & $\$ 16,000$ & $\$ 32,000$ \\
\hline$\$ 1000$ & 6.4 & 16 & 32 \\
$\$ 2500$ & 2.56 & 6.4 & 12.8 \\
$\$ 5000$ & 1.28 & 3.2 & 6.4 \\
\hline
\end{tabular}

the potential efficiency of management programs given different cost scenarios.

\subsection{Benefit-cost analysis}

The benefit-cost analysis (BCA) follows the framework outlined in Engeman et al. (2002, 2003) and Shwiff et al. (2003). The BCA of herpetofauna management involves estimating the monetary value of the benefits measured in the dollar value of animals saved by reduced road-kills versus the costs measured in the amount spent to reduce road-kills. In this study, the number of animals saved each year represents the benefits of a hypothetical road-kill management program. Benefits were calculated by multiplying the number of animals saved each year by the value of each individual animal ( $\$ 100, \$ 250$ and $\$ 500)$. A range of values $(\$ 1000, \$ 2500$ and $\$ 5000$ ) was also used to estimate the annual total cost of a road-kill management program.

The benefit-cost ratios (BCRs) are calculated using the standard format of the ratio of benefits to costs (Loomis and Walsh, 1997; Boardman et al., 1996; Nas, 1996; Zerbe and Dively, 1994; Loomis, 1993). In general, the BCRs for this analysis were calculated from the equation

$\mathrm{BCR}=\frac{\text { Total Value of Animals Saved }}{\text { Road }- \text { kill Management Costs }}$

A value of 1.0 indicates no net benefit or cost (dollar savings in animals saved). For example, the annual BCR for reducing road-kill by 96 animals each valued at $\$ 500$ with management costing of $\$ 1000$ would be 48 , i.e., the value of the animals saved is 48 times greater than the cost of management for that year.

\section{Results}

Two hundred fifty six individual animals, representing 2 turtle species, 2 lizard species, 15 snake species, American alligators, 3 frog species and various unidentified aquatic turtles, snakes and anurans were recorded as road-kills during the study period (Table 1), averaging 64 animals per year. Using the three values for herpetofauna ( $\$ 100, \$ 250$, and $\$ 500$ ) to estimate the benefits of road-kill management provided an economic sensitivity analysis. Total losses using the three animal values were $\$ 25,600, \$ 64,000$, and $\$ 128,000$, respectively. Had we substituted the Endangered Species Act value of $\$ 25,000$ for the eastern indigo snake (Drymarchon corais), the total economic loss would have been $\$ 50,500, \$ 88,750$ and $\$ 152,500$, respectively. The prevention of some or all of these losses through a management program provides an economic benefit.

Substituting the appropriate values into Eq. (1) and completing this process for all values of animal and management costs yields the annual BCRs in Table 2. This assumes all 64 animal losses per year would have been averted. A sensitivity analysis varying the number of animals saved per year provides an alternative approach to estimating the BCRs of a hypothetical management program. Table 3 examines three scenarios. Each scenario assumes an animal value of $\$ 100, \$ 250$ or $\$ 500$. A range is provided under each scenario for the number of animals saved and program costs. This allows for sensitivity analysis to determine the conditions under which the program is economically efficient.

Under the first scenario (panel A), each animal is valued at $\$ 100$. The benefit-cost ratios (BCRs) range from 0.2 to 6 . The best BCR (6) results from the lowest program cost of $\$ 1000$ and 60 animals saved annually. The worst BCR (0.2) results from the highest program cost of $\$ 5000$ and only 10 animals saved annually. A program scenario is economically inefficient when BCR values are less than one, which indicates that the costs exceed the benefits. There are six such scenarios presented in panel A. There are two breakeven points $(B C R=1)$ under this first scenario, when program costs are

Table 3 - A benefit-cost sensitivity analysis for averting amphibian and reptile road kills in Jonathan Dickinson State Park, Florida, where the management costs, number of animals saved and values of animals are varied

Panel A: benefit-cost ratios at $\$ 100 /$ animal

\begin{tabular}{lccc}
\hline \multirow{2}{*}{$\begin{array}{c}\text { Number } \\
\text { saved }\end{array}$} & \multicolumn{3}{c}{ Management costs } \\
\cline { 2 - 4 } & $\$ 1000$ & $\$ 2500$ & $\$ 5000$ \\
\hline 10 & 1 & 0.4 & 0.2 \\
20 & 2 & 0.8 & 0.4 \\
30 & 3 & 1.2 & 0.6 \\
40 & 4 & 1.6 & 0.8 \\
50 & 5 & 2.0 & 1.0 \\
60 & 6 & 2.4 & 1.2
\end{tabular}

Panel B: benefit-cost ratios at $\$ 250$ / animal

\begin{tabular}{llll}
\hline $\begin{array}{c}\text { Number } \\
\text { saved }\end{array}$ & \multicolumn{3}{c}{ Management costs } \\
\cline { 2 - 4 } & $\$ 1000$ & $\$ 2500$ & $\$ 5000$
\end{tabular}

$\begin{array}{lrll}10 & 2.5 & 1 & 0.5 \\ 20 & 5.0 & 2 & 1.0 \\ 30 & 7.5 & 3 & 1.5 \\ 40 & 10.0 & 4 & 2.0 \\ 50 & 12.5 & 5 & 2.5 \\ 60 & 15.0 & 6 & 3.0\end{array}$

Panel C: benefit-cost ratios at $\$ 500 /$ animal

\begin{tabular}{cccc}
\hline \multirow{2}{*}{$\begin{array}{c}\text { Number } \\
\text { saved }\end{array}$} & \multicolumn{3}{c}{ Management costs } \\
\cline { 2 - 4 } & $\$ 1000$ & $\$ 2500$ & $\$ 5000$ \\
\hline 10 & 5 & 2 & 1 \\
20 & 10 & 4 & 2 \\
30 & 15 & 6 & 3 \\
40 & 20 & 8 & 4 \\
50 & 25 & 10 & 5 \\
60 & 30 & 12 & 6 \\
\hline
\end{tabular}

Management costs with benefit-cost ratios $>1$ are economically justified as the returns exceed the financial outlay. 
$\$ 1000$ and 10 animals are saved annually and when program costs are $\$ 5000$ and 50 animals are saved annually. Under each of these conditions there is no net program benefit. All BCRs greater than one indicate that the benefits of the program exceed the costs, which represents economic efficiency. There are ten such scenarios presented in panel A.

The second scenario presented in panel $B$ represents an animal value of $\$ 250$. BCRs ranged from 0.5 to 15 . With a higher animal value the number of inefficient points is diminished to only one, when program costs are $\$ 5000$ and only 10 animals are saved annually. As in panel A there are two breakeven points presented in panel B, when program costs are $\$ 2500$ and only 10 animals are saved annually, and when program costs are $\$ 5000$ and 20 animals are saved annually. The number of efficient points jumps dramatically to 15 under this scenario.

The highest animal value of $\$ 500$ is used in the final scenario presented in panel $\mathrm{C}$. In this scenario there is only one breakeven point at a program cost of $\$ 5000$ and only 10 animals saved. All of the other scenarios are economically efficient. The highest BCR indicates that benefits are 30 times greater than the costs, and at the very worst case the benefits equal the costs.

\section{Discussion}

A variety of management actions can be implemented to reduce reptile and amphibian road-kills. These can range from greater enforcement of speed limits to provision of structural devices to deter herpetofauna from the roadways. For example, wildlife underpasses below roadways have been retrofitted on micro scales (Jackson and Tyning, 1989), and grandiose scales (Foster and Humphrey, 1995), with varying degrees of success and costs. Benefit-cost ratios of management actions to protect wildlife can be calculated and considered in the manner of Engeman et al. $(2002,2004)$ and Shwiff et al. (2003) so that they are justified in both a biological, and increasingly economic, conservation arena. This will justify testing and use of innovative techniques to further reduce traffic-related mortality, especially for (higher valued) critically imperiled herpetofauna taxa.

For JDSP, there was an average of 64 herpetofauna roadkills per year with an average annual valuation conservatively ranging from $\$ 6400$ to over $\$ 32,000$. Also, the number of roadkills observed undoubtedly is a conservative figure. Even though the roads were searched daily, some road-kills likely were lost to scavenging or obliteration by traffic, or otherwise rendered impossible to observe. Moreover, a proportion of animals involved in collisions with vehicles die off of the road where they would not be observed during road surveys. Nevertheless, the dollar amounts provide baseline figures for evaluating expenditures proposed to reduce losses. A hypothetical benefit-cost analysis allows for a case by case analysis of the possible expenditures needed to reduce losses to a level that would result in both economic efficiency and conservation benefits. Varying the animal values, program costs and number of animals saved annually provides a sensitivity analysis allowing the examination of a wide array of management strategies simultaneously. Wildlife managers can identify the best conservation strategy after determining the program costs and animal value.

By necessity, economic analyses take a "shopping cart" approach to valuing species, whereby a "price tag" is applied to the individual of each species. The credibility of an analysis hinges on the logical application of a valuation procedure. Conservative benefit-cost analyses using lower species values tend to lead to greater acceptance of the results, but should be accompanied by the knowledge that the actual benefit-cost ratio could be much higher. The use of a range of values provides a more robust analysis that allows for the examination of results under varying cost conditions. However, estimated replacement costs do not compensate for the immediate loss of biotic potential within demes, nor for the more consequential, irretrievable loss of pooled genetic variation through subsequent generations. Unfortunately, it is impossible to ascribe monetary value to the loss of random mating events and the infinite possibilities for genetic recombination associated with them.

\section{R E F E R E N C E S}

Ashley, E.P., Robinson, J.T., 1996. Road mortality of amphibians, reptiles and other wildlife on the Long Point Causeway, Lake Erie, Ontario. Canadian Field-Naturalist 110, 403-412.

Bard, A.M., Smith, H.T., Egensteiner, E.D., Mulholland, R., Harbor, T.V., Heath, G.W., Miller, W.J.B., Weske, J.S., 2002. A simple structural method to reduce road-kills of royal terns at bridge sites. Wildlife Society Bulletin 30, 603-605.

Boardman, Anthony E., Greenberg, D.H., Vining, A.R., Weimer, D.L., 1996. Cost-Benefit Analysis: Concepts and Practice. Prentice Hall, Upper Saddle River, New Jersey, pp. 187-205.

Bodenchuk, M.J., Mason, J.R., Pitt, W.C., 2002. Economics of predation management in relation to agriculture, wildlife, and human health and safety. In: Clark, L. (Ed.), Proceedings of the 1st International Symposium on the Economics of Wildlife Damage Management. Colorado State University, Fort Collins, pp. 80-90.

Engeman, R.M., Shwiff, S.A., Constantin, B., Stahl, M., Smith, H.T., 2002. An economic analysis of predator removal approaches for protecting marine turtle nests at Hobe Sound National Wildlife Refuge. Ecological Economics 42, 469-478.

Engeman, R.M., Shwiff, S.A., Cano, F., Constantin, B., 2003. An economic assessment of the potential for predator management to benefit Puerto Rican parrots. Ecological Economics 46, 283-292.

Engeman, R.M., Shwiff, S.A., Smith, H.T., Constantin, B., 2004. Monetary valuation of endangered species and imperiled habitats as a basis for economically evaluating conservation approaches. Endangered Species Update 21, 66-73.

Florida Department of Environmental Protection, 2000. Jonathan Dickinson State Park Unit Management Plan. State of Florida. Department of Environmental Protection, Tallahassee, Florida.

Foster, M.L., Humphrey, S.R., 1995. Use of highway underpasses by Florida panthers and other wildlife. Wildlife Society Bulletin 23, 95-100.

Haxton, T., 2000. Road mortality of snapping turtles, Chelydra serpentina, in central Ontario during their nesting period. Canadian Field-Naturalist 114, 106-110.

Hels, T., Buchwald, E., 2001. The effect of road kills on amphibian populations. Biological Conservation 99, 331-340.

Jackson, S.D., Tyning, T.F., 1989. Effectiveness of drift fences and tunnels for moving spotted salamanders (Ambystoma maculatum) under roads. In: Langton, T.E.S. (Ed.), Amphibians and roads. Proceedings Of The Toad Tunnel Conference. ACO Polymer Products, Shefford, England, pp. 93-99. 
Loomis, J.B., 1993. Integrated Public Lands Management: Principles and Applications to National Forests, Parks, Wildlife Refuges and BLM Lands. Columbia University Press, New York, pp. 116-170.

Loomis, J.B., Walsh, R.G., 1997. Recreation Economic Decisions: Comparing Benefits and Costs, 2nd Edition. Venture Publishing, Inc., State College, Pennsylvania, pp. 369-410.

Nas, T.F., 1996. Cost-Benefit Analysis: Theory and Application. Sage Publications, Inc., California, pp. 57-66.

Shwiff, S.A., Smith, H.T., Bard, A.M., Harbor, T.V., Heath, G.W., Engeman, R.M., 2003. An economic analysis of a simple structural method to reduce road-kills of royal terns at bridges. Caribbean Journal of Science 39, 250-253.

Smith, H.T., Miller, W.J.B., Roberts, R.E., Tamborski, C.V., Timmerman, W.W., Weske, J.S., 1994. Banded Royal Terns recovered at Sebastian Inlet, Florida. Florida Field Naturalist $22,81-83$.

Smith, H.T., Barry, R.M., Engeman, R.M., Shwiff, S.A., Miller, W.J.B., 2003. Species composition and legal economic value of wildlife road-kills in an urban park in Florida. Florida Field Naturalist 31, 53-58.

Trombulak, S.C., Frissell, C.A., 2000. Review of ecological effects of roads on terrestrial and aquatic communities. Conservation Biology 14, 18-30.

Zerbe, R.O., Dively, D.D., 1994. Benefit-Cost Analysis: In Theory and Practice. HarperCollins College Publishers, New York, NY, pp. 369-394. 